\title{
A REFORMA DA PREVIDÊNCIA SOCIAL BRASILEIRA entre o direito social e o mercado
}

Ademir Alves da Silva

\footnotetext{
Resumo: Este texto trata da gestão do sistema previdenciário brasileiro, identificando as posições em confronto, em dois períodos: o imediatamente posterior à reforma de 1998, do governo FHC, e o do primeiro ano do governo Lula.

Palavras-chave: política social; seguridade social; previdência social.

Abstract: This text deals with the administration of the Brazilian social welfare system, identifying the opposite positions in two periods: the period subsequent to the 1998 Reform, in FHC government, and the first year of Lula's government.

Key words: social politics; social security; social welfare.
}

A

polêmica em torno de alternativas para a gestão do sistema previdenciário remete aos fundamentos do papel do Estado e de sua relação com a sociedade, pondo em questão o modelo de desenvolvimento econômico dominante na América Latina e no Brasil na última década do século XX. Sob a égide do chamado projeto neoliberal, malgrado todos os efeitos danosos registrados particularmente no que concerne às políticas sociais, esse modelo parece persistir ainda nos primeiros anos deste século.

Este texto ${ }^{1}$ aborda os principais aspectos do tema, identificando as posições em confronto, em dois períodos: o imediatamente posterior à reforma de 1998, do governo FHC, e o do primeiro ano do governo Lula. Embora as reformas desses períodos já estejam consubstanciadas em emendas constitucionais, as questões relacionadas à gestão, não apenas da previdência social, mas da seguridade social brasileira como um todo, estão longe do cabal e duradouro equacionamento, o que atesta a pertinência e a oportunidade do presente estudo.

\section{A PREVIDÊNCIA SOCIAL PÓS-REFORMA DE 1998}

A Europa e a América Latina têm sido palco de intensa polêmica e de medidas inovadoras em torno da reforma de seus sistemas de seguridade social em razão da chamada crise fiscal do Estado. De fato, o desequilíbrio das contas públicas vem constituindo o grande argumento em favor da redução das despesas previdenciárias, como - no caso da América Latina e, particularmente, do Brasil uma das formas de liberar recursos para o pagamento de juros e encargos da dívida pública.

Associados à questão do déficit fiscal, comparecem o desemprego da década de 90 e as mudanças nas relações de trabalho orientadas pelo critério da flexibilização, a par da crescente informalidade. As baixas taxas de crescimento econômico, com queda da arrecadação previdenciária, combinadas com o aumento da longevidade da população têm conduzido ao crescimento desproporcional do universo de beneficiários inativos em face dos contribuintes em atividade. 
As mudanças até agora ocorreram em contexto de adesão ao ideário neoliberal, voltado à recuperação ou reafirmação dos fundamentos da economia capitalista, sob hegemonia da fração financeira do capital, sendo o Estado sujeito e objeto da reforma. A ênfase no desequilíbrio orçamentário da seguridade e do próprio Estado privilegia a criação de condições para a restauração das relações econômicas que oneram o trabalho e desoneram o capital ou que impedem a ampliação dos custos do sistema de seguridade pela taxação do capital, mediante mecanismos de transferência de renda, com um sentido distributivo.

No Brasil, as novas regras derivadas da Emenda Constitucional - EC n. 20/98 representaram, com efeito, a imposição de perdas aos segurados, uma vez que o eixo da reforma foi o aumento da idade média de concessão do benefício, implicando extensão do período contributivo, redução dos gastos no curto prazo pela postergação da concessão e redução dos gastos no longo prazo pela concessão por menor período (CECHIN, 2002, p. 23).

Trata-se de trabalhar mais, contribuir mais e receber menos, estreitando a relação entre contribuições e benefícios pela nova regra de cálculo.

Parece haver consenso em torno das medidas modernizantes da gestão do sistema, da inversão do ônus da prova, do reconhecimento automático de direitos, ${ }^{2}$ da lei de crimes contra a previdência social, ${ }^{3}$ do aprimoramento das medidas de ampliação de arrecadação, da criação de mecanismos de atração para a filiação, ${ }^{4}$ do combate à sonegação e à fraude, do fim dos privilégios e injustiças, da necessidade de ampliação da cobertura, do papel social pela transferência de renda e combate à pobreza, ou mesmo da necessidade de previdência complementar, entre outros aspectos.

O acordo, todavia, logo se desfaz quando os argumentos em favor da continuidade e ampliação da reforma são outros, tais como: o da reprodução da desigualdade, da solidariedade invertida, da esperteza corporativista do servidor público, do impacto de benefícios assistenciais sem base contributiva, do déficit incontrolável, da introdução de elementos atuariais no sistema por meio do fator previdenciário, da modernização da gestão do sistema ou da superação da "gestão pouco técnica, arbitrária e intransparente" (SCHWARZER, 1999, p. 29).

A seguir, estes últimos argumentos, objeto de intensa polêmica, são analisados separadamente e, depois, em conjunto.

\section{A Reprodução da Desigualdade}

Segundo pesquisadores e técnicos da área, nossos sistemas de proteção social foram mais mecanismos de reprodução da desigualdade estrutural de nossas sociedades do que instrumentos de incorporação dos segmentos economicamente excluídos ou de redução das diferenças sociais. Com efeito, os gastos com os sistemas de aposentadorias e pensões, incluindo os regimes especiais dos funcionários públicos, representam a parcela majoritária dos dispêndios sociais e ultrapassam, na grande maioria dos países, $10 \%$ do produto nacional, ainda que a cobertura em geral seja limitada e tenha fortes aportes fiscais. Não obstante tenha ocorrido um processo gradual de ampliação da cobertura, tanto horizontal como vertical, em geral, esta não abarca a maioria da população economicamente ativa. Na verdade, não chegamos a conhecer o Estado de Bem Estar Social. A cultura do privilégio nos levou muitas vezes ao Estado do mal-estar social que, ao reproduzir as estruturas de desigualdade do modelo de crescimento econômico, em geral não foi capaz de resolver os problemas das maiorias [...] Com efeito, o custeio do sistema de seguridade social se baseia em recursos tributários ou parafiscais que incidem sobre diversas etapas da cadeia produtiva [...] incorporados ao custo da produção, gravando, portanto, o preço final de bens e serviços e repercutindo na competitividade da economia. Até que ponto se poderá sacrificar a competitividade em nome da preservação ou da implementação de políticas de bem-estar social e viceversa? (MORAES, 1999, p. 4).

Está aí uma questão que, certamente, divide os interlocutores. Colocada como oposição entre competitividade e bem-estar social, a seguridade social tende, sem dúvida, a sucumbir sob a ditadura do mercado. Mas, se a questão central é, realmente, a ampliação da cobertura e a reversão da desigualdade, então prevalece o princípio da seguridade universal, cuja aplicação prática depende do mercado - retomada do crescimento econômico, geração de empregos, filiação à previdência, aumento da arrecadação e garantia de cobertura -, mas não se subordina a ele. Os aportes tributários e parafiscais não representam fenômeno externo, alheios e autônomos em relação ao anseio por bem-estar social, mas como parcela do excedente econômico apropriada pelo Estado, são constitutivos da riqueza social, patrimônio coletivo. E por que dissociar a política social da política econômica, opondo-as? Ou, ao contrário do que ocorreu ao longo da segunda metade do século XX, estaria descar- 
tada a perspectiva de compatibilização da seguridade social com a economia de mercado, como estratégia essencial de regulação social?

\section{A Solidariedade Invertida}

Quanto à solidariedade invertida, que se articula à reprodução da desigualdade, segundo o ex-ministro José Cechin (2002, p. 9-13):

No caso do Brasil, caso não houvesse uma reforma no sistema previdenciário, estaria perpetuando-se uma perversa redistribuição de renda, via Previdência Social, em que os mais pobres financiavam os mais ricos. E um dos mecanismos que possibilitavam essa espécie de solidariedade às avessas era a aposentadoria por tempo de serviço. O perfil dos beneficiários da aposentadoria por tempo de serviço era o de trabalhadores que tinham em média 48,9 anos, provinham, em grande parte, de postos de trabalho de melhor qualidade, com salários mais elevados e uma vida laboral mais estável, facilitando, portanto, a comprovação, especialmente em termos de documentação, dos requisitos para a obtenção da aposentadoria. O valor médio da aposentadoria era de $R \$ 515,71-2,3$ vezes superior à média de todos os beneficios. [...] Em outro extremo [...] encontravamse os trabalhadores que se aposentavam por idade, com, em média, 62,8 anos. Eram pessoas com menor poder aquisitivo e apresentavam dificuldade de comprovação do tempo de serviço, devido à maior instabilidade de suas vidas laborais. Seus postos de trabalho eram mais precários, caracterizados por alta rotatividade, baixa qualificação e baixos salários. O valor médio da aposentadoria por idade, de $R \$$ 145,18, era cerca de 3,6 vezes menor do que o valor médio da aposentadoria por tempo de serviço. Assim, configuravase um sistema de solidariedade às avessas [...] só existente no Brasil e em mais três países, Equador, Irã e Iraque.

Desnecessário reafirmar a necessidade de combater os mecanismos pelos quais os pobres financiam os ricos. $\mathrm{E}$ não apenas no interior do sistema previdenciário que, inevitavelmente, constitui um reflexo da estrutura socioeconômica da qual se alimenta e que ajuda a reproduzir, esta sim, profundamente desigual. Em outros termos, as condições de trabalho, de inserção ocupacional, de aferição de renda e de qualidade de vida na aposentadoria, que opõem "contribuintes mais ricos" a "contribuintes mais pobres", extrapolam o âmbito do sistema previdenciário, embora possam ser - e efetivamente o são - reproduzidas por ele, como no caso em análise, ao exprimirem um pa- drão de socialidade em si mesmo iníquo e reprodutor da desigualdade.

Portanto, o dissenso não decorre do imperioso compromisso ético-político de combater, no interior do sistema previdenciário, os mecanismos reprodutores da desigualdade, mas da tendência de se nivelar por baixo a pauta de direitos sociais, nesse caso expressos em garantia de renda, a pretexto de combater privilégios, opondo trabalhadores entre si e transferindo renda de uns para os outros, preservando, em última análise, os ganhos do capital. E quanto à transferência de renda, se é verdade que não se pretende que os "mais pobres" continuem a financiar os "mais ricos", é de se perguntar em que medida a reforma contribuiu, efetivamente, para inverter a situação, transferindo para aqueles o que não mais será pago a estes, além da possível redução da concessão de benefícios, "aliviando" o caixa do sistema por determinado período.

\section{A Esperteza Corporativista do Setor Público}

Quanto aos propalados privilégios e disfunções ${ }^{5}$ da previdência do setor público, a campanha que se desenvolveu, na década de 90, contra o Estado - acusado de ineficiente, corrupto, esbanjador de recursos e mau patrão - não poderia deixar de capturar, no argumento pela desarticulação do aparelho estatal e das políticas públicas em favor do mercado, a sua figura central - o servidor público. Fortaleceu-se certa concepção de que o funcionário público é, por definição, um perdulário do dinheiro público, gozando de privilégios jamais sonhados pelo trabalhador do setor privado.

Ora, não se trata de acabar com o serviço público - ou se trata? - a pretexto de combater a ineficiência e suprimir privilégios. Sem dúvida, os favorecimentos e as disfunções têm que ser enfrentados. Porém, a discussão quanto ao serviço público é eivada de armadilhas, das quais é preciso desvencilhar-se.

Interesses puramente mercantis - e, portanto, privatistas -, atentos e fiéis às recomendações do Banco Mundial e do FMI, vêm permeando, na América Latina, os embates em torno da reforma do Estado e da seguridade social. Ora, trata-se de combater o patrimonialismo que, historicamente, marcou a cultura político-institucional, postulando a recuperação do papel do Estado na gestão do interesse público, orientada pela busca de excelência na qualidade de serviços prestados ao cidadão. Isso requer investimentos na capacitação e consolidação de quadros de servidores que estejam aptos a responder pela opera- 
ção de agências governamentais articuladas em uma rede de apoio ao cidadão - portador de direitos civis, políticos e sociais - caracterizada pela qualidade e resolubilidade dos serviços prestados. O que implica, evidentemente, combater a corrupção e a ineficiência, ações que não significam a desqualificação do que se faz para justificar a redução de gastos em relação àquilo que, na realidade, não se quer fazer - entenda-se -, favorecendo o mercado.

Com efeito, será necessário suprimir privilégios, criar condições para maior eficiência dos serviços e rever velhas concepções em torno da constituição de feudos no interior do serviço público. Trata-se, pois, de qualificar o servidor público pelo concurso, pela carreira, pela avaliação de desempenho, pela política salarial, pela seguridade social, pela preservação de direitos adquiridos.

Sob tal perspectiva, embora temporariamente descartada pelo governo, a proposta de unificação de regimes o do setor privado e o do setor público - teria que considerar os critérios que, até agora, vêm orientando a relação do servidor público com o seu trabalho e com a sociedade: o ingresso por concurso, a investidura em um cargo público com direitos e deveres estabelecidos em um estatuto da categoria, a participação na gestão de negócios de interesse público, a estabilidade do vínculo em face da alternância das coalizões governamentais, a ascensão por mérito na carreira.

A contratação de servidores públicos pelo Regime Geral da Previdência Social - RGPS, conforme prevê a Lei n. 9.962/2000, submete-os às regras do setor privado, ou seja, com instabilidade no emprego e redução de vencimentos na aposentadoria. De novo, contrapõem-se os trabalhadores e agora sob condições antiisonômicas, a pretexto de combater a desigualdade. E, em ambos os casos, os trabalhadores são forçados a migrar para a previdência complementar privada. No mesmo serviço público haverá funcionários estáveis, com direito a aposentadoria integral, e outros instáveis, sem vencimentos integrais na aposentadoria, reafirmando a desigualdade dentro do próprio serviço público.

É certo que os diversos regimes municipais ou estaduais deverão ser submetidos a revisão, sob o princípio da responsabilidade fiscal. E em alguns casos terá mesmo que ser redimensionada a contribuição previdenciária dos servidores ativos. ${ }^{6}$ Mas, isso não significa compactuar com medidas tendentes ao confisco, seja pela redução dos benefícios, seja pela cobrança de contribuição dos inativos, até porque o servidor público, ao contrário do empregado do setor privado, não dispõe da poupança compulsória representada pelo FGTS. Tratase, no caso do FGTS, de uma reserva que, se não utilizada para outros fins durante o período laboral, poderá complementar a renda na aposentadoria, o que tem sido um dos argumentos para a manutenção dos vencimentos integrais do servidor público inativo, que não conta com essa poupança. ${ }^{7}$

\section{O Impacto de Benefícios Assistenciais sem Base Contributiva}

O impacto negativo de benefícios assistenciais sem base contributiva - o Benefício de Prestação Continuada - nas contas previdenciárias é tributário da concepção de proteção social frente ao risco, reduzida à noção de seguro social, dependente das oscilações do mercado, em geral, e do mercado de trabalho, em particular.

Um dos avanços da Constituição Federal de 1988 foi a inclusão da assistência social no elenco dos direitos sociais constitutivos da cidadania - compondo, com a saúde e a previdência, o Sistema de Seguridade Social. Isso é visto por segmentos progressistas como assistencialização $o^{8}$ da previdência, e pelos liberais, como agravante do déficit, a demandar aportes fiscais. No segundo caso, os argumentos não conseguem disfarçar a intenção restauradora do mérito individual como garantia do acesso a serviços e benefícios, sob a lógica mercantil. Há um discurso recorrente contra a incorporação da assistência social ao Sistema de Seguridade Social, como ocorreu na Constituinte de 1988. Trata-se da assistência social "pura e simples” (LAHÓZ, 2003, p. 35-ss), que, segundo os defensores da previdência reduzida a seguro, deve ser desmembrada da seguridade social, especialmente pelo fato de ser um benefício sem contribuição prévia.

Ora, o sistema de seguridade social brasileiro, malgrado tratar-se do que apresenta a maior cobertura social no continente latino-americano, é

tão acanhado, [...] composto apenas de três politicas sociais [...] e sem as necessárias unicidade e organicidade conceitual, institucional e financeira (PEREIRA, 2000, p. 85).

Então, é preciso resistir à tendência de dissociar a política social da política econômica e a seguridade social do mercado. A seguridade social não pode sucumbir às pressões em favor da liberdade do mercado em face dos constrangimentos - para este último - de ter que finan- 
ciar e manter a seguridade social, especialmente em seu elenco de benefícios "não contributivos", pelo que representam como mecanismos de transferência de renda para os mais pobres. Contributivos ou fiscais, os recursos constituem parcela da riqueza social, cuja gestão e distribuição deve responder a critérios de solidariedade, de universalidade e de justiça social.

Segundo o ex-ministro José Cechin (2002, p. 39-40, grifo meu),

evoluiu-se para o conceito de Previdência como seguro social [...] Previdência é de caráter contributivo, tanto no setor privado quanto no serviço público. $O$ acesso a um benefício pressupõe o pagamento dos prêmios do seguro. O esquema que melhor implementa esta idéia é o modelo de capitalização individual do estilo chileno [...] Há muito por se fazer para que o sistema previdenciário siga de perto critérios de seguro social, que garantam o equilíbrio atuarial.

Na realidade, houve um retrocesso. Reduzir seguridade a previdência e esta a seguro implica passar a utilizar no seu âmbito todas as estratégias tipicamente mercantis, quais sejam: selecionar riscos de menor custo, recusar certos riscos como objeto de seguro, transferir riscos e prejuízos para o "segurado". Em suma, trata-se da substituição da seguridade pela incerteza em face do risco - ou seja, mais um risco -, prevalecendo o "salve-se quem puder", sob a égide da rentabilidade, no âmbito individual, sem as garantias de um pacto coletivo.

Quanto ao paradigma chileno, não adianta tergiversar:

Contrariamente ao que se tem difundido, os dados mais recentes sobre a experiência da reforma no Chile, relativos ao ano de 2001, evidenciam fortemente a sua inadequação como modelo a ser seguido: o gasto público elevou-se em função do chamado 'custo de transição', a cobertura previdenciária reduziu-se, o custo administrativo previdenciário aumentou e o valor dos benefícios oscila de acordo com a flutuação do mercado financeiro, gerando incertezas. Além disso, no Chile, a alta concentração dos ativos previdenciários em mãos de poucas administradoras privadas está gerando oligopolização do mercado (GUSHIKEN et al., 2002, p. 14, NR 6).

Em outros termos,

a solução chilena parece não ser a mais eficiente. Mas, com certeza, ela é caríssima e um meganegócio para o setor financeiro à custa do contribuinte (SCHWARZER, 1997).
Definitivamente - a história já demonstrou à exaustão -, aumento de estoque de capital não representa, necessariamente, melhoria de condições de vida e bem-estar social. ${ }^{9}$

\section{Déficit Incontrolável}

A recorrente questão do déficit, na verdade o maior motivo declarado para a reforma, também é objeto de dissenso, desde a concepção até a base de dados.

Segundo o Ipea (2002, p. 15), o déficit foi de R\$13,3 bilhões em 2001, ou seja, 1,08\% do PIB. Ocorre que o RGPS foi superavitário durante longo período, até 1995, quando se iniciou a tendência de déficits (GUSHIKEN ET AL., 2002, p. 13, NR 5). De um superávit de R\$ 16,6 bilhões em 1988, registrou-se um déficit de R $\$ 9,1$ bilhões em 1998 (CECHIN, 2002, p. 14).

A redução do déficit nos últimos anos é apontada como efeito da reforma, combinada com outros fatores. Segundo Pinheiro (2001, p. 34), de janeiro a outubro de 2001, o déficit foi $6,6 \%$ menor que o de 2000 , considerada também a recuperação da economia no período, com maior massa salarial e, conseqüentemente, maior base de arrecadação.

Afinal, a reforma de 1998 reverteu a tendência de déficit? Há mais dúvidas - no máximo, projeções - do que certezas.

No caso da previdência do servidor público federal,

a tendência é de decréscimo no déficit. Hoje, nós estamos no fundo do poço em relação à previdência do setor público. Para o futuro, considerando que não vai mais haver ingressos no sistema, a tendência é a diminuição do déficit. É lógico que isso ocorrerá em um período muito grande - a projeção se alastra até 2070. Mas, nesse periodo, que vai até 2015, o déficit fica mais ou menos estável, talvez crescendo um pouco, mas a partir dai deve diminuir (PINHEIRO, 2001, p. 40).

Já no Regime Geral de Previdência Social,

as medidas implementadas proporcionaram a melhora na performance da arrecadação e o aprimoramento dos mecanismos de recuperação de créditos, além de terem condicionado a redução da taxa de crescimento da despesa para patamares inferiores aos observados anteriormente. Neste sentido, os resultados financeiros foram alterados de maneira consistente no curto e longo prazos, revertendo a trajetória explosiva do déficit previdenciário. Hoje, pode-se dizer que o déficit do RGPS no curto prazo é relativamente 
controlável, a depender principalmente de variáveis políticas, como o aumento do salário real para o salário mínimo, e macroeconómicas, como o ritmo de crescimento do PIB [...] a relação déficit/PIB apresentará, no período entre 2003 e 2005, uma queda em função do rápido crescimento esperado para o PIB. A partir de 2006, esta relação apresentará uma trajetória de crescimento, estabilizando-se em torno de 1,20\% entre 2013 e 2021. Caso não houvesse reforma, o déficit chegaria a 3,6\% do PIB no mesmo periodo (CECHIN, 2002, p. 25, grifos meus).

Portanto, registra-se uma tendência de reversão, tornando controlável o déficit, embora persistente.

[...] a previdência social fechou o primeiro ano pós-reforma com um déficit de $R \$ 10,07$ bilhões, equivalente a 0,9\% do Produto Interno Bruto - PIB. Esse resultado foi considerado bastante satisfatório, pois estava sendo a primeira vez que o déficit, enquanto proporção do PIB, registrava queda em cinco anos. Contudo, em 2001, o déficit novamente aumentou ( $R \$ 12,8$ bilhões), representando 1,08\% do PIB (MARQUES et al., 2003, p. 116).

Todavia, põe-se em questão o próprio conceito de déficit utilizado pelo Ministério da Previdência e Assistência Social - MPAS, enfocando setorialmente a previdência e não a seguridade social em seu conjunto. As citações que se seguem, embora longas, são fundamentais:

Considerando esse conceito de proteção social (o da Constituição de 1988), não seria apropriado calcular isoladamente as contas da previdência social, tal como previsto na Lei de Responsabilidade Fiscal. [...] seu resultado negativo é reflexo, antes de tudo, do desempenho da economia brasileira que, se voltasse a crescer e a gerar emprego no mercado formal de trabalho, superaria rapidamente sua situação de déficit. Essa argumentação não desconsidera, entretanto, que, em termos contábeis, seja apurado o resultado da previdência social. O que se estranha é o fato de o governo federal nunca se preocupar em contabilizar e divulgar para toda a sociedade o resultado do conjunto da seguridade social. Em 1999, por exemplo, ano em que a reforma foi aprovada e a previdência registrava um déficit equivalente a $1 \%$ do PIB, a seguridade social apresentava um superávit de R\$16,3 bilhões, correspondendo a 1,7\% do PIB. Em 2001, adotando-se o mesmo critério, o superávit da seguridade social aumentou para $R \$ 32,1$ bilhões, cerca de 2,6\% do PIB (MARQUES et al., 2003, p. 117, grifos meus).
A Constituição de 88 determina que as contribuições sociais, ou seja, Cofins sobre o faturamento das empresas, a CSLL - Contribuição sobre o Lucro Líquido, e de empregados e empregadores sobre a folha salarial devem se destinar exclusivamente para o financiamento da seguridade social que, no Brasil, congrega as ações de saúde, assistência e previdência social. A seguridade não inclui os benefícios propiciados a servidores públicos regidos por estatutos próprios. Considerando essa definição, o Brasil teria um superávit da seguridade, não fazendo sentido falar em déficit da previdencia. [...] O texto constitucional prevê, ainda, se necessário, a utilização de recursos do Orçamento Fiscal para completar o montante necessário ao financiamento do sistema, ainda que o Orçamento da Seguridade Social seja plenamente suficiente para arcar com o custeio dos seus programas fins. Assim, ao se falar no déficit ou superávit [...], seria necessário considerar as receitas e despesas deste conjunto e não somente a arrecadação do INSS e as respectivas despesas com benefícios previdenciários e assistenciais (ANFIP, 2002, p. 14;24, grifos meus).

Não existe déficit, porque tem de computar nas receitas as contribuições que foram criadas para isso. Se computar $R \$$ 45 bilhões de Cofins, quase $R \$ 9$ bilhões de Contribuição Social sobre o Lucro Líquido, já não há déficit. Em 2001, teria tido um superávit de $R \$ 34$ bilhões na Previdência. Se computar ainda a contribuição da União que não é feita, ai é que não tem déficit mesmo. Tem que apurar isso. Se pegarem os desvios, dinheiro que foi para obras ${ }^{10}$ (grifos meus).

Se considerada em seu conjunto - setor privado e setor público -, a seguridade é superavitária e estável. Em 2002, o superávit foi de R\$ 15 bilhões (MARQUES, 2003; TAVARES, 2003).

Além da questão quanto ao conceito ou critério utilizado para contabilizar o déficit, é impossível chegar a conclusão inequívoca sobre o comportamento dos benefícios e afirmar que a tendência de reversão do déficit - se admitida - seja devida ao impacto da reforma ou que expresse o crescimento vegetativo da demanda contida ou antecipada - de benefícios, em face de situações atípicas desde 1986: as novas regras de cálculo e de acesso a partir da Constituição Federal de 1988, com aumento de benefícios em 1992-93 e a "corrida à aposentadoria" em 1997, face às expectativas quanto às mudanças que ocorreriam a partir de 1998. E, considerando-se as três categorias de demandantes de benefícios - os que já rece- biam benefícios antes da 
reforma; aqueles em transição sob as regras anteriores; e os ingressantes sob as novas regras -, esperava-se mesmo pequeno impacto da reforma sobre os benefícios, no curto prazo (MARQUES et al., 2003).

Parece que relativo sucesso pode ser constatado pelo lado do aprimoramento dos mecanismos de arrecadação, tais como: a retenção, que consiste na cobrança de contribuições de empresas terceirizadas; o recolhimento de depósitos judiciais na Justiça do Trabalho; a renegociação da dívida de Estados e Municípios; os certificados da dívida pública como instrumentos de recuperação de crédito (PINHEIRO, 2001, p. 29).

Entretanto, tão remotas quanto atuais, tão recorrentes quanto jamais superadas, recolocam-se as questões do desvio de recursos ${ }^{11}$ e de sua má gestão, das fraudes e da sonegação. E não é surpreendente que, no encalço das propostas de reforma, reacenda a proposta de auditoria externa do sistema.

A auditoria deve combinar-se, evidentemente, com medidas administrativas, judiciais e - quando for o caso - policiais para combater o desvio, a fraude, ${ }^{12}$ a sonegação ${ }^{13}$ e a evasão de recursos constitutivos do patrimônio coletivo da seguridade social.

Mas o principal desvio refere-se ao pagamento dos juros das dívidas interna e externa, ${ }^{14}$ o que remete à busca de condições para a renegociação dos débitos, extrapolando a alegada crise da previdência.

\section{Impacto do Fator Previdenciário}

Quanto ao impacto do fator previdenciário ${ }^{15}$ há, igualmente, divergentes avaliações. Em face da resistência de segmentos do Congresso Nacional ao aumento da idade mínima para aposentadoria, na ocasião da discussão do projeto de reforma, o Executivo propôs - e, então, aprovou - o fator previdenciário. Do ponto de vista do governo, tratou-se de um grande avanço em favor do equilíbrio atuarial entre os benefícios e as contribuições. Do ponto de vista de organizações representativas de trabalhadores, o fator representou um confisco parcial do valor da aposentadoria, impondo perdas aos segurados, no caso do setor privado.

Esse fator prejudica os mais pobres e as mulheres, além de estabelecer em relação ao cálculo anterior um redutor de $30 \%$ nas aposentadorias, obrigando todos a trabalharem mais para garantir o mesmo nivel de aposentadoria da lei anterior (CUT, 2002).
O achatamento prejudica, principalmente quem começa a trabalhar mais cedo, o que ocorre com a maioria da massa trabalhadora. A alteração é profunda e afeta homens e mulheres. Só que as mulheres perdem mais, caso se aposentem após cumprir 30 anos de contribuição, tempo mínimo exigido, terão uma perda de até $50 \%$ do valor do beneficio a que teriam direito. Serão obrigadas a renunciar à justa aposentadoria e trabalhar pelo menos 10 anos a mais para recuperar o que está sendo retirado. Os homens também perdem muito. Mesmo que tenha cumprido os 35 anos de contribuição, exigidos como tempo mínimo, o trabalhador que tenha começado sua vida profissional aos 15 anos, aos 50 anos, tendo completado o tempo de contribuição, perderá $30 \%$ do valor no seu beneficio. Para recuperar a perda terá que trabalhar mais cinco anos (CUT, s.d.).

Trata-se, portanto, de um redutor (PENNA, 1999), obrigando todos a trabalhar mais. Pelo fator previdenciário, com o aumento da expectativa de vida, cai o valor da aposentadoria. O fator impõe o adiamento da aposentadoria. A postergação significa que quanto mais velho o trabalhador, mais ele ganha - em princípio -, por menos tempo. E quanto mais novo se aposenta, menos ganha, por mais tempo. Então, a longevidade é uma punição. Em outros termos, significa mais anos de vida com menos dinheiro no bolso. E a aposentadoria por tempo de serviço - e de contribuição, portanto - foi severamente desvalorizada.

A introdução do fator previdenciário no cálculo da aposentadoria parece estar longe de equacionar o problema que a motivou, uma vez que não há suficientes evidências de que se esteja em vias de obter o alegado equilíbrio atuarial, a despeito da redução dos futuros benefícios. ${ }^{16}$

É certo que

apesar de reduções de gasto diminutas nos primeiros anos, os gastos no médio e longo prazo após a aprovação da emenda são maiores do que se nada fosse feito (OLIVEIRA, 2000).

Vale destacar que os "ganhos" com a eliminação da aposentadoria proporcional e a postergação da apsentadoria, então com salário integral, são neutralizados por um acréscimo de $42,86 \%$ ao valor médio dos benefícios. Além disso, a tentativa de implantar a contribuição dos inativos, derrubada por uma liminar no STF, inviabilizou judicialmente a referida cobrança até para alguns Estados e municípios que já a praticavam. Ao contrário do que foi anunciado - maior ganho para quem postergar a aposentadoria -, o fator previdenciário implicará perdas 
da ordem de $40 \%$ quando aplicado na integralidade (após cinco anos do período de transição, portanto, a partir de 2004), em função da "elevadíssima taxa intertemporal com que as pessoas descontam valores futuros" (OLIVEIRA, 2000, p. 2). ${ }^{17}$

Então, por que o fator previdenciário é perverso? Porque impõe o confisco e posterga, sem resolver, o alegado problema, pelo menos na forma em que tem sido formulado e apresentado à sociedade por representantes do governo e pela mídia conservadora.

\section{Modernização da Gestão}

A modernização da gestão do sistema é outro ponto controvertido. Às declarações dos ministros do governo de Fernando Henrique Cardoso é possível contrapor as preocupações do ministro do governo de Luís Inácio Lula da Silva:

Pretendemos fazer uma análise profunda do gargalo tecnológico da Dataprev. Para o tamanho das informações do INSS - são 21 milhões de benefícios e mais de 50 milhões de contribuintes, entre pessoas fisicas e jurídicas -, a Dataprev tem um parque tecnológico sucateado, funcionários mal remunerados e uma situação de relacionamento com o INSS tensa, por causa das falhas. Às vezes, as agências ficam duas horas sem sistema porque o sistema não agüenta a demanda nacional. Os bancos investem centenas de milhões de reais em informática para ter controle contra fraudes e mesmo assim são objeto de fraude. Esse tipo de investimento, no Ministério, não vem ocorrendo de forma sistemática. ${ }^{18}$

Ou seja, o sistema de processamento, nas condições aqui apontadas, favorece a fraude e não assegura a agilidade, a resolubilidade, a confiabilidade e a transparência das informações.

E o próprio quadro de pessoal é insuficiente para a ação fiscal. Segundo a Associação Nacional dos Fiscais de Contribuições Previdenciárias - Anfip (2002, p. 46-47):

cada fiscal arrecada o equivalente a $R \$ 2,7$ milhões por ano, segundo dados da Diretoria de Arrecadação e Fiscalização do INSS. Com a quantidade atual de cerca de 3.800 auditores-fiscais, o resultado da ação fiscal - RAF chegou a $R \$ 9,4$ bilhões no primeiro semestre de 2002, quantia equivalente a cerca de $30 \%$ da arrecadação líquida total. Com 8 mil, o RAF poderia alcançar um montante duas vezes maior, contribuindo para a melhoria do equilíbrio financeiro do sistema.
De qualquer modo, a perspectiva de realização de concurso para a contratação de 3.800 funcionários parece equacionar, ainda que parcialmente, o problema, considerando-se os 18 anos decorridos sem qualquer concurso para ingresso no quadro de pessoal da Previdência Social. $^{19}$

Admitindo-se a necessidade da reforma - ou de sua continuidade -, quais seriam os parâmetros? O que é possível depreender da análise da posição dos últimos ministros e outros integrantes da gestão de Fernando Henrique Cardoso, no âmbito da Previdência Social?

Para Pinheiro (2001, p. 39), no caso do servidor público, "a bomba está desarmada para o futuro", uma vez que estão equacionados problemas de fluxo (novos servidores ingressarão pelo RGPS, estatutários terão a previdência complementar em substituição à aposentadoria integral), mas ainda é necessário equacionar os problemas de estoque relacionados aos atuais ativos e aposentados: aumentar a contribuição dos ativos, cobrar contribuição dos inativos, punir os maus dirigentes conforme a Lei de Responsabilidade Fiscal, criar incentivos para desistência da aposentadoria integral e migração para o sistema complementar. De modo geral, seria necessário, segundo o autor: aprimorar o sistema do RGPS, acabar gradualmente com a previdência do setor público e desenvolver o sistema de previdência complementar.

José Cechin (2002, p. 52), último ministro da Previdência da gestão FHC, defende a seguinte agenda para a continuidade da reforma: revisão das alíquotas de contribuição; estímulo à postergação das aposentadorias por tempo de contribuição; especialização das alíquotas em financiamento de benefícios de risco (doença, invalidez, acidente e morte em serviço) e financiamento de benefícios programáveis (aposentadoria); revisão do acúmulo de benefícios ou de benefício e salário; separação do financiamento dos benefícios sem a suficiente contrapartida contributiva; revisão das idades da aposentadoria rural.

Ou seja, o que se preconiza é a unificação dos atuais regimes de gestão pública, o fortalecimento do seguro privado (inclusive, abrindo à concorrência a cobertura do seguro de acidentes de trabalho) sob o pretexto da renda complementar e, em suma, a continuidade de imposição de perdas aos trabalhadores urbanos e rurais: trabalhar mais tempo (idade mínima na cidade, revisão da idade no campo e postergação da aposentadoria), pagar mais (revisão de alíquotas de ativos, cobrança de inativos) e reduzir os ganhos (fim da aposentadoria integral, revisão do acúmulo de benefício e salário). E fica claro o retro- 
cesso na concepção de seguridade social (separação dos benefícios que não tenham suficiente contrapartida contributiva).

Ora, a defesa da previdência social solidária, de gestão pública, democrática e universal, significa postular muito mais do que ela é hoje: cobertura restrita e benefícios equiparados - para $65 \%$ dos beneficiários - ao salário mínimo, que, sabidamente, está muito longe de ser suficiente para suprir necessidades humanas vitais de uma unidade familiar que não disponha de outras fontes de renda. E, dentre os argumentos em favor da reforma, o mais facilmente defensável é o que se refere à necessidade de expansão da cobertura.

A atual cobertura é de 39,9\% da População Economicamente Ativa - PEA (MPAS, 2002, p. 17), sendo de $77,3 \%$ a cobertura de pessoas com mais de 60 anos (IPEA, 2002, p. 15). Estão fora da previdência 40,2 milhões de pessoas, ou seja, $60 \%$ da população ocupada no setor privado (CECHIN, 2002, p. 41). Desse universo de não filiados que poderiam, em princípio, filiar-se, 11,3 milhões são trabalhadores por conta própria, domésticos e empresários e outros 7,5 milhões ganham mais de um salário mínimo, sem carteira assinada, nos setores de serviços, construção civil e agricultura (CECHIN, 2002, p. 42). Trata-se, portanto, de pouco para poucos. A maioria está fora do sistema previdenciário.

\section{A POLÊMICA PRÉ-REFORMA - 2003}

Após a posse do presidente Luís Inácio Lula da Silva, a mídia desencadeou um movimento a favor da reforma realizada com a Emenda Constitucional n. 20/98, fazendo recorrentes menções ao próprio programa de governo, no qual a reforma previdenciária figurava entre as prioridades.

Acusado de ser o "maior ralo de dinheiro público do país" (EXAME, 2003) ou causador do "desequilíbrio das contas públicas" (VEJA, 2003), o crescimento do déficit é o recorrente argumento em favor da reforma. E, de novo, o alvo é o chamado desequilíbrio atuarial do sistema, ${ }^{20}$ seja pela queda do número de contribuintes em relação aos beneficiários inativos, pelos privilégios do sistema, pela incorporação à conta da previdência de benefícios assistenciais não contributivos, ou, especialmente, pela aposentadoria integral do servidor público. O foco foi, sem dúvida, a aposentadoria do servidor público.

Em janeiro de 2003, o Poder Executivo encaminhou ao Congresso Nacional uma proposta de emenda à Cons- tituição. É possível identificar os pontos centrais da polêmica, a partir de declarações do ministro Ricardo Berzoini quanto aos principais aspectos da reforma preconizada pelo governo.

A proposta consistia, inicialmente, em regime único para o setor privado e público, teto único, aposentadoria complementar por meio de fundos de pensões, contribuição de $20 \%$ sobre o faturamento e não sobre a folha salarial das empresas, regra de transição pro rata ${ }^{21}$ e contribuição dos inativos. Mas a contribuição de inativos seria descartada em face da inevitável querela - de difícil superação - desencadeada quanto à argüição de inconstitucionalidade da medida.

Após a intensa polêmica que marcou o primeiro semestre de 2003 - incluindo-se as manifestações de servidores públicos contra o projeto de reforma, as pressões dos governadores, os recuos e reposicionamentos do governo federal -, o relatório final da comissão parlamentar definiu os seguintes pontos:

- aposentadoria integral, desde que cumpridos os requisitos de dez anos na carreira, 20 anos de serviço público, 35 e 30 anos de contribuição e 60 e 55 anos de idade (para homens e mulheres, respectivamente);

- benefício calculado pela média das contribuições para os servidores que não cumprirem as exigências para a aposentadoria integral;

- teto de salário e aposentadoria de $\mathrm{R} \$ 17.170,00$ para a União, para Estados e municípios, subteto salarial igual ao salário do chefe de cada um dos três Poderes, e, para o Judiciário Estadual, teto de $75 \%$ do salário do ministro do STF;

- teto de R\$2.400,00 para ingressantes no serviço público e trabalhadores da iniciativa privada;

- aposentadoria complementar por meio de fundo de pensão;

- extinção da aposentadoria proporcional para servidores que ingressaram até 1998;

- idade mínima de 55 anos para a mulher e de 60 anos para o homem;

- pensões integrais até o valor de R\$1.058,00 e desconto mínimo de $30 \%$ sobre a parcela excedente;

- fim da paridade e correção dos benefícios pela inflação para servidores que não cumprirem requisitos para aposentadoria integral;

- paridade parcial para aposentadorias integrais com correção restrita ao salário-base; 
- contribuição de $11 \%$ de inativos atuais e futuros sobre a parcela de benefícios superior a $\mathrm{R} \$ 1.058,00$;

- alíquota mínima de contribuição de 11\% para União, Estados e Municípios. ${ }^{22}$

Com a proposta de extinção da aposentadoria integral do servidor público, objeto de intensa polêmica, a noção de direito revelou-se inteiramente dependente da circunstância histórica que, ao contrapor interesses e cotejar posições na arena jurídico-política, remete, inelutavelmente, aos fundamentos da ordem econômica e social.

Ora, a questão da sustentabilidade do sistema previdenciário não se esgota na esfera do direito, que, se por um lado representa garantias sob a tutela jurisdicional, por outro não se desvencilha dos mecanismos fundamentais de reprodução e manutenção da ordem socioeconômica. Em outros termos, não é possível abstrair o direito da base material da sociedade. Não é outro o sentido da polêmica que opõe direito presumido a direito adquirido ou direito acumulado a direito consolidado, a pretexto de preservação ou de extinção da integralidade da aposentadoria. Está em questão, simplesmente, a irretroatividade da lei.

A insegurança no plano das relações econômicas expressa-se, então, no plano jurídico-político, na forma de instabilidade de regras, violação ou revogação de princípios constitucionais, esgarçamento da expectativa de direito como marca do Estado democrático. Trata-se, a rigor, da fragilidade de um contrato social à mercê das exigências da política econômica ou fiscal em vigor.

De novo, procura-se opor os trabalhadores - os do setor privado aos do setor público. ${ }^{23}$ Tenta-se, ainda, nivelar por baixo os direitos sociais, criando anteparos à elevação de custos para o capital, na forma de parcela do excedente econômico apropriada e gerida pelo Estado, pelos instrumentos fiscais, tributários e contributivos.

É o que se demonstra, a seguir, cotejando as propostas que comparecem ao debate. Após apresentação geral da proposta de reforma, discorre-se sobre as posições identificadas na imprensa conservadora e nas organizações representativas de trabalhadores de diferentes perfis. No primeiro caso, foram selecionadas duas matérias, uma da revista Veja e outra da revista Exame. No segundo caso, arrolaram-se as posições da Força Sindical, da Central Única dos Trabalhadores, da Federação Nacional de Servidores do Judiciário Federal - Fenajufe, da Associação Nacional dos Fiscais de Contribuições Previdenciárias Anfip e do Sindicato Nacional dos Auditores-Fiscais da Receita Federal - Unafisco Sindical. ${ }^{24}$
A imprensa conservadora insiste no argumento da inviabilidade do sistema público de repartição e recupera o mérito individual: "cada trabalhador financia seu próprio futuro e recebe de acordo com suas contribuições" (AMARAL; BARELLI, 2003), segundo a lógica mercantil, defende o regime de capitalização e exige que o Estado faça a reforma e promova o "ajuste fiscal duradouro", de modo a "honrar compromissos, fazer cair o risco-país, reduzir o juro interno, retomar o crescimento sustentado" (LAHÓZ, 2003).

Para o mercado, em outros termos, a reforma é importante para evitar o colapso fiscal do país; dar visibilidade de longo prazo às contas brasileiras; tirar o país da zona de risco de moratória da dívida; reduzir a avaliação de risco do país; abrir espaço para cortes nas taxas de juros; criar um ambiente mais favorável ao investimento; permitir à economia crescer sem causar impacto na inflação (OTTA; MURPHY, 2003).

Qual é a posição das organizações representativas dos trabalhadores?

Segundo a Unafisco Sindical, a reforma tributária deveria preceder a reforma previdenciária. O sistema tributário é concentrador de renda, onera a classe média e privilegia o capital com a "pouca tributação sobre o patrimônio e isenção do juro sobre o capital próprio". O alegado déficit da previdência precisa ser depurado de valores como despesas de pessoal. De novo, a proposta de reforma orienta-se pela lógica fiscal e do capital financeiro. ${ }^{25}$

Para a Anfip (2002), o debate atual oculta o fato de a previdência pertencer ao Sistema de Seguridade Social. E os maiores problemas para a geração de receitas são as renúncias fiscais; as perdas de arrecadação; a sonegação fiscal pelo subfaturamento; o estoque da dívida previdenciária, com cerca de R\$ 125 bilhões da dívida ativa em dezembro de 2001; a debilitação das relações de trabalho; a queda da massa salarial ou a reduzida base de contribuintes regulares e a exclusão da proteção pela limitação da renda e pela imagem negativa da previdência. Em face de tal situação, as condições para a manutenção do sistema seriam: aumento do número de contribuintes; maior estabilidade das relações de trabalho com o crescimento do assalariamento e a regularização de contratos de trabalho; retomada do crescimento do PIB; revisão dos métodos gerenciais; fiscalização da arrecadação; revisão do regulamento de benefícios; garantia do caráter redistributivo e garantia de direitos sociais, sob pena de elevação da desigualdade já existente no Brasil. Para a Anfip, portanto, a previdência pública é 
viável e o mais promissor mecanismo de articulação entre a economia e a sociedade para promover o desenvolvimento. Trata-se de resgatar o papel da seguridade, melhorando os serviços, concebendo a proteção social como núcleo da estratégia para a retomada do crescimento econômico.

A Fenajufe (2002), com base em ampla análise dos contextos latino-americano e brasileiro em que se realizam reformas, declara-se contrária à política de privatização, aponta o "declínio do neoliberalismo como saída para o impasse" da crise capitalista contemporânea e, afinal, reafirma os princípios da irredutibilidade salarial, da paridade entre ativos e inativos, do custeio parcial por empregadores privados ou estatais e da responsabilidade integral e absoluta do Estado pela manutenção do sistema e pela garantia de um direito social coletivo. Postula, portanto, um sistema de previdência social público, único, sob gestão estatal - democrática e transparente - com participação de representantes dos trabalhadores nos conselhos de administração, assegurada a integralidade dos proventos na aposentadoria.

Contestando recomendações do Banco Mundial e imposições do FMI quanto à previdência nos acordos para concessão de empréstimos, a CUT (2002) preconiza uma previdência geral pública, de gestão paritária, com teto de 20 salários mínimos tanto para o setor privado quanto para o setor público e complementação por meio de fundos de pensão. Reitera o combate à sonegação e a renúncia previdenciária em favor das falsas "filantrópicas". Defende a gestão pública do Seguro de Acidentes do Trabalho - SAT e questiona a proposta de fixação de idade mínima sem considerar realidades regionais e características do trabalho realizado. Propõe ainda a ampliação dos benefícios assistenciais. E, sob a perspectiva da defesa da previdência pública e solidária, propõe a revogação da EC n. 20/98 e as leis subseqüentes da reforma (CUT, 2002).

O que se depreende da análise das manifestações aqui confrontadas? De um lado, a crítica ao sistema público de previdência social, acusado de injusto e perdulário, agora destacando o regime dos servidores públicos; a exigência de ajuste fiscal; a pressão para desonerar o capital pela redução da carga tributária ou para esconjurar pretensas ampliações do chamado "custo Brasil", a pretexto de geração de novos empregos; a defesa da "competitividade"; a restauração da cultura do mérito individual; e a consonância com a lógica mercantil pela defesa do regime de capitalização. De outro lado, a defesa da previdência pública, de gestão democrática, propondo padrões e limites a serem observados no projeto de reforma, não estando, entretanto, suficientemente claras as posições quanto à proposta de regime único.

A seguir, analisam-se os principais aspectos apontados, que remetem aos fundamentos da seguridade social e da economia capitalista contemporânea.

\section{Privatização}

Toda a reforma do Estado brasileiro orientou-se por uma estratégia de progressivo e crescente favorecimento do mercado, o que equivale à privatização. No Plano Diretor da Reforma do Estado, do governo FHC, no setor de atividades exclusivas (não lucrativas) ou monopolistas do Estado, figura a previdência básica. Básica em relação ao conjunto das operações da área, a serem crescentemente assumidas pelas entidades abertas e fechadas de previdência privada. Básica no sentido de pagamento mínimo para pessoas cujos ganhos já são mínimos ou inexistentes: trabalhadores de baixa renda com vínculo formal de trabalho filiados ao sistema, idosos e deficientes, não contribuintes, admitido, com relutância, o seu direito à seguridade social.

As baixas taxas de crescimento econômico, o desemprego estrutural, ${ }^{26}$ a informalidade do mercado de trabalho, a não filiação ao sistema (impossibilitando o aumento de arrecadação) e mesmo a falta de credibilidade no sistema agora agravada com a permanente ameaça de confisco pela reforma - são fatores que contribuem para incentivar, de fato, a privatização, a julgar pelo sucesso da previdência privada. O mercado pede flexibilização, desregulação e privatização. E há um evidente interesse de seguradoras e bancos privados no estoque de recursos geridos pelos fundos de pensão, que, por sua vez, apropriam parcela da renda dos trabalhadores a título de capitalização e formação de reservas para complementar a aposentadoria. ${ }^{27}$

O governo FHC afastou a proposta de substituição do regime de repartição pelo de capitalização individual privada, em razão dos elevados custos da transição, tendo como modelos o do Chile e o da Argentina.

No caso do Chile, questiona-se mesmo se houve privatização ou, em outros termos, quais foram os limites da propalada privatização, uma vez que

o Estado regula a demanda (através das contribuições compulsórias), regula a oferta (supervisionando as AFPs), financia parte das pensões, administra e financia o antigo sistema (OLIVEIRA et al., 1999, p. 47). 
No caso da Argentina,

há margem para acreditar que o sistema de previdência privada [...] venha a ter dificuldades para cumprir suas promessas de fornecer beneficios mais adequados e para mais pessoas do que um sistema público reformado poderia ter sido capaz de proporcionar a um grau de risco financeiro muito inferior. Mantida a tendência, provavelmente a Argentina terá de proceder a uma reestatização do sistema de fundos de pensão privados em momento futuro, assim que as questões mais prementes da estabilização macroeconômica tenham sido resolvidas (IPEA, 2002, grifo meu). ${ }^{28}$

Então, as "soluções de mercado" têm mostrado resultados desastrosos não apenas por privilegiarem a rentabilidade e reproduzirem a desigualdade social, mas também por serem incapazes de honrarem os próprios postulados e intenções retóricas. É um mercado "livre" que nada faz sem o Estado e que, mais que isso, quer o Estado cúmplice do Diktat mercantil.

Reatualiza-se, destarte, a recorrente questão quanto ao caráter do seguro - no âmbito do mercado e não apenas da previdência social - na sociedade contemporânea: qual o modelo que se postula?

[...] o da solidariedade, onde o seguro significa proteção da vida, da saúde, dos bens dos cidadãos brasileiros e no qual há que se inserir a preocupação com o caráter social do seguro? Ou o do risco, onde o seguro antes de tudo é considerado investimento, mais um serviço financeiro prestado pelos grandes conglomerados? Ou uma combinação de ambos? (ALBERTI et al., 1998, p. 296). ${ }^{29}$

\section{Unificação dos Regimes}

Quanto à unificação dos regimes, ${ }^{30}$ além da relação entre setor público e setor privado, caso venha a ser retomada, terão que ser equacionadas algumas bipolaridades, como: filiados e não filiados, contribuintes e não contribuintes, condições para o homem e condições para a mulher, trabalhador urbano e trabalhador rural.

O regime único e universal deve respeitar a diferença, sob pena de reproduzir a desigualdade. Se se trata de consolidar o sistema de seguridade social brasileiro, então o desafio é ampliar a cobertura - pela inclusão daqueles que por falta de trabalho, por insuficiência de renda, por absoluta impossibilidade de contribuição prévia ou mesmo por desconfiança encontram-se fora do sistema -, aumentando o número de filiados e de contribuintes, o que re- mete à retomada do crescimento econômico e à ampliação das oportunidades de emprego.

A composição e o papel da família encontram-se em franca mudança, valendo ressaltar o desempenho da mulher como protagonista - e não apenas na manutenção da coesão de famílias matriarcais -, pondo em questão as funções e os efeitos econômicos do trabalho doméstico não remunerado e modificando o perfil do mercado de trabalho. Então, qualquer modelo que se venha a adotar terá que equacionar a diferente inserção da mulher nas relações de trabalho, sob condições diferenciadas, tais como a descontinuidade do vínculo, a maternidade e a condição cultural e histórica - longe de ser superada - de cuidadora $^{31}$ dos demais membros da família. Nas diversas condições é a mulher que cuida de criança, idoso, doente, portador de deficiência, etc.

Quanto à relação urbano-rural, é sabido que a vida no campo se urbaniza em vários sentidos, como no acesso aos meios de comunicação, aos serviços e aos hábitos de consumo. E é evidente a tendência de trabalhar no campo sem viver ali confinado, morando no núcleo rurourbano, na agrovila, na pequena cidade. Isso está longe de significar condições de trabalho similares às da cidade, a não ser pela informalidade, pela precariedade do contrato, pela baixa remuneração e pela redução de oportunidades em razão da mecanização da produção. Além de reproduzirem o que se passa na cidade no que diz respeito à debilitação do trabalho, as condições laborais no campo são reconhecidamente mais deletérias, dependendo da inserção ocupacional e do "contrato". Então, assim como no caso do trabalho urbano, deve-se considerar o grau de exposição a riscos sociais, ambientais, ergonômicos, físicos, emocionais, em suma, a salubridade.

A extensão da cobertura previdenciária ao trabalhador rural, com a criação do Funrural, em 1971, depois incorporado ao INPS, foi um significativo avanço da seguridade social brasileira, ainda que essa cobertura seja freqüentemente apontada como um fator de agravamento do déficit, por se tratar de concessão de benefícios que não tiveram contrapartida da contribuição.

[...] o Prorural/Funrural representou um múltiplo rompimento com os princípios do seguro social de padrão contributivo bismarckiano, que caracterizaram a história da previdência social na América Latina no século $X X$. Houve a ruptura com as noções de que: 1. a um benefício deve corresponder uma contribuição; 2. essa contribuição deve ser tripartite (segurado, empregador e Estado); e 3. 
o beneficio resultante deve estar vinculado ao padrão de rendimentos pregressos do segurado. O próprio fato de o beneficio ser de valor constante flat-rate, uma característica mais presente em paradigmas de proteção social universalistas, constitui uma inovação em relação à tradição brasileira e latino-americana em geral. Outro elemento diferenciador consiste no fato de que há, no programa, redistribuição de renda no sentido urbano-rural, contrarestando, ao menos parcialmente, o subsidio rural-urbano implicito na forma de financiamento dos sistemas urbanos via contribuição sobre a folha salarial, cuja parcela patronal geralmente é repassada para os preços dos bens consumidos também na área rural (MALLOY apud DELGADO; SCHWARZER, s.d.).

Então, trata-se de preservar, aprimorar e ampliar a cobertura previdenciária do trabalhador rural, como parte de uma estratégia de distribuição mais justa da renda nacional.

\section{Piso e Teto de Benefícios}

Esta questão remete às condições de existência coletiva que se deseja preservar, aprimorar ou superar. Referese a padrões de vida como expressão das relações sociais. Hábitos de consumo, graus de acesso a bens, recursos e serviços e condições de vida, longe de se restringirem a preferências, escolhas pessoais e adesões seletivas, exprimem modos de ser socialmente determinados. Direitos são expressões de luta social e política, condensando possibilidades e limites de pactos coletivos, sob determinadas condições históricas. Então, as noções de básico, vital, mínimo, razoável, máximo, excelente ou ideal, todas adjetivas, prestam-se a estabelecer os parâmetros para outras noções, estas sim substantivas, relacionadas às várias formas de apropriação de parcelas da riqueza social, das quais a renda é inequívoca, mas nem por isso suficiente. São noções mutáveis, relativas, dependentes das condições objetivas em que se dá a produção e a apropriação de riqueza.

Integralidade (e não parcialidade), irredutibilidade (e não redutibilidade) e paridade (e não disparidade) são princípios de justiça social. Por que a aposentadoria tem que ser punida com a redução de renda? Por que o tempo livre tem que significar queda do padrão de vida, opondo ativos e inativos? Quem estaria impondo tais condições a quem?

Piso e teto não podem ser discutidos em si mesmos, fora das relações econômicas. Observa-se forte tendência em colocar a questão dos ganhos da aposentadoria no plano dos privilégios, para justificar o confisco geral, nivelando por baixo a pauta de direitos sociais. Por que a discussão é tão intensa em torno da renda do trabalho, mas fraca quanto à do patrimônio e do capital? ${ }^{32}$ Aqui, seria justo compartilhar da posição da Anfip de que a reforma tributária deveria preceder a reforma previdenciária.

Admitindo-se um teto para o valor da aposentadoria do servidor público - o atual teto do setor privado é de $\mathrm{R} \$ 1.561,00$ e as propostas em debate oscilaram entre 10 e 20 salários mínimos, ou seja, R\$2.400,00 e R\$ $4.800,00^{33}$-, seria razoável considerar que $67,3 \%$ dos funcionários do Executivo Federal já ganham abaixo de R\$ 2 mil. ${ }^{34}$ Considerado todo o país, estima-se que $80 \%$ dos funcionários públicos já recebam abaixo de $\mathrm{R} \$$ $1.561,00$ por mês, o teto do INSS. ${ }^{35}$

Ao propor um teto de 20 salários mínimos, a CUT procurou assegurar salários integrais para a maioria dos trabalhadores do setor público, preservando, na realidade, o princípio da irredutibilidade salarial, estabelecido pela Constituição Federal.

\section{Financiamento}

Não há como reduzir o problema do financiamento ao "desencaixe atuarial", à desproporção entre contribuintes e beneficiários, à oposição entre trabalhadores do setor privado e do setor público, ao aumento de contribuições e à redução de benefícios e, em suma, aos mecanismos de maior expropriação do trabalho. O que está em questão não é apenas o equilíbrio atuarial das contas da previdência, mas o equilíbrio e a coesão da sociedade com base em formas mais justas de apropriação e fruição da riqueza social.

As pressões pela reforma da previdência social respondem a uma estratégia de mercantilização da seguridade social, ou seja, a um processo de privatização. ${ }^{36}$ Assim, a previdência se converte em um produto, a compor o portfólio de bancos e seguradoras, no caso das entidades privadas, ou passa a depender dos investimentos rentáveis, sem compromisso com o desenvolvimento social, no caso dos fundos de pensão.

De qualquer modo, há associação - maior ou menor ao capital internacional, pela observância das recomendações do Banco Mundial e do FMI e pela incorporação da experiência européia ou norte-americana, naquilo em que representam poder e sucesso no mercado de capitais. Qual poder? E que sucesso? ${ }^{37}$ 


\section{CONCLUSÃO}

Da análise realizada, depreende-se que a polêmica em torno da reforma oculta, conforme a posição adotada, revela interesses que extrapolam o sistema previdenciário público, dissocia a política da economia, reduz a concepção de seguridade social ao cálculo financeiro e atuarial, isola a questão do déficit da relacionada ao financiamento das ações do Estado, omite as exigências do Banco Mundial e do FMI, relativiza o caráter redistributivo das políticas sociais e representa mais uma forma de confisco aos trabalhadores, opondo os do setor privado aos do setor público. Em última análise, privilegia o capital, particularmente sua fração financeira, e expropria o trabalho.

A previdência é um campo de batalha de uma guerra maior. É inaceitável que seja imputada à previdência social, isoladamente, a responsabilidade pela deterioração das contas públicas. O que está em crise é um modo de organização e gestão da vida social. O que está em jogo são os interesses de favorecimento da "competitividade" do capital em detrimento das políticas sociais.

A crise econômica é que determina as alegadas dificuldades da previdência, e não o contrário. A previdência depende do crescimento econômico e do mercado de trabalho, e não o contrário. Inaceitável, portanto, que o ônus da crise, agravada sob as políticas neoliberais, recaia sobre os funcionários públicos e que o propalado déficit seja atribuído à não contribuição prévia do trabalhador rural ou dos beneficiários da assistência social, ao reajuste do salário mínimo que corresponde ao valor dos benefícios de dois terços dos segurados do setor privado ou ao reajuste anual das pensões dos demais segurados.

A reforma da previdência é necessária, mas está longe de ser solução para uma crise da qual é apenas uma das expressões. Qual reforma é desejada? A que concebe a previdência como parte da seguridade social, expressão de um pacto coletivo e solidário e que, portanto, resiste à privatização. Que consolida o democrático Estado de Direito, honrando compromissos e respeitando contratos com os trabalhadores. Que não impõe novas perdas aos segurados por meio de fatores de confisco. Que equacione piso e teto, parâmetros e padrões, iguais e diferentes, na esfera do direito social - portanto, na arena do interesse público - sem reduzir tudo a produtos, segundo a lógica mercantil, sabidamente reprodutora da desigualdade social.

\section{NOTAS}

1. Este texto foi elaborado com base na tese de doutorado do autor (SILVA, 2003).

2. A Lei n. 10.843, de 08/01/02, estabelece o reconhecimento automático de direitos com base nos registros da Previdência Social, desobrigando o segurado de apresentar documentos para provar tempo e valor das contribuições.

3. Lei n. 9.983/00 ou Lei de Crimes contra a Previdência Social, versa sobre apropriação indébita, sonegação e omissão de informações.

4. Concessão de salário-maternidade para autônomas; compensação entre contribuições de empregados e empregadores (setor rural e contribuintes individuais empregados por empresas); retenção da contribuição que consiste na antecipação da receita em relação a setores terceirizados; divulgação de informações ao público (PINHEIRO, 2001, p. 38-39).

5. "A lista de disfunções é grande, envolvendo a profusão de regimes próprios criados no âmbito dos municípios e Estados, os quais, desamparados de controle social, absolutamente não transparentes e desprovidos de homogeneização nas regras previdenciárias e administrativas, criaram facilidades para fraudes, incentivaram a prática abusiva de concessão de aposentadorias extremamente generosas protagonizadas por grupos corporativos, desviaram recursos para atividades não previdenciárias, não sendo raros os casos em que os Tesouros locais não repassavam suas respectivas contribuições à entidade ou ao órgão gestor e mantiveram sob o mesmo abrigo contábil e financeiro benefícios assistenciais e previdenciários, financiados, via de regra, por contribuições estabelecidas por critérios políticos, sem o menor rigor técnico" (GUSHIKEN et al., 2002, p. 19). "Era no setor público onde ocorria o maior número de aposentadorias precoces, acumulação de aposentadorias, acumulação de aposentadoria com salário de outro emprego, e onde era maior a duração dos benefícios e menor o prazo de carência [...] No serviço público, os diferentes regimes e critérios permitiam que alguns se aposentassem mais de uma vez e ainda voltassem a ocupar emprego público. A acumulação de aposentadorias - e estas de valor igual à remuneração da ativa - gerava os super-salários [...] As tendências indicavam gastos com aposentadorias e pensões de tal magnitude, que inviabilizariam as administrações públicas, com a compressão dos salários dos trabalhadores da ativa e diminuição da disponibilidade de recursos para as políticas públicas locais" (CECHIN, 2002, p. 14-17).

6. Conforme já ocorreu no Estado de São Paulo, que antes tinha, a menor alíquota de contribuição previdenciária dos servidores ativos $(6 \%)$, elevada para $11 \%$, aproximando-se da alíquota da maioria dos Estados (de $10 \%$ a $14 \%$ ).

7. Vale registrar, não obstante, que "Em vários Estados da União existe contribuição de inativos, inclusive diferençada por faixa de renda. De acordo com o Relatório Anual da Previdência Social de 1999, [...] a contribuição dos aposentados é de 3,5\% em Minas Gerais, de 4\% a $5 \%$ no Acre, de 5\% na Bahia, de 6\% em São Paulo, de 7,4\% no Rio Grande do Sul, de $8 \%$ em Roraima, de 9\% em Tocantins, de 11\% no Rio de Janeiro, de $8 \%$ a $12 \%$ em Santa Catarina e Mato Grosso, de $11 \%$ (até R\$ $1.200,00$ ) a 20\% no Amazonas, de $10 \%$ (até R $\$ 1.200,00$ ) a $20 \%$ no Paraná e de $10 \%$ (até R\$ 200,00) a 20\% (acima de R\$ $1.200,00)$ em Pernambuco. Não havia contribuições em Roraima, Pará, Amapá, Piauí, Ceará, Rio Grande do Norte, Paraíba, Alagoas, Mato Grosso do Sul, Goiás e Distrito Federal. Como existem ações na Justiça relativas a essas contribuições, a situação pode ter mudado. Alguns Estados (12) também impõem contribuições aos pensionistas" (FALEIROS, 2000, p. 111-112, grifos meus).

8. É desalentador constatar, mesmo nos governos de coalizões de centro-esquerda, o embate entre a afirmação e a recusa da assistência social como política pública provedora de bens e serviços no âmbito da seguridade social. 
9. Ao analisar três modelos teóricos para a previdência social, Miranda (1997, p. 49, grifos meus) conclui que: "é importante frisar que a adoção de um ou outro modelo tem sérias implicações sobre as formulações de política econômica e, em especial, sobre os resultados a serem esperados de uma reforma no sistema previdenciário. No modelo de Diamond, uma migração do sistema Pay-as-you-go para o fully funded poderia ampliar o estoque de capital da economia, mas não necessariamente ampliaria o bem-estar, pois poderia levar o sistema econômico a um estado de ineficiência dinâmica. Sob a perspectiva do modelo de Barros, essa reforma seria incapaz de ampliar o estoque de capital da economia, uma vez que os agentes privados compensariam por completo a redistribuição intergeracional de riqueza promovida pelo governo. No modelo de Martins, por sua vez, uma reforma desse teor aumentaria a acumulação de capital, mas, não necessariamente ampliaria o bem-estar, pois nesse caso haveria um decréscimo nas heranças doadas. De qualquer forma, o incremento da poupança gerado no modelo de Diamond estaria amplamente superestimado quando contrastado com aquele obtido a partir do modelo de Martins".

10. Presidente da Unafisco Sindical, Paulo Gil Introíni, em entrevista à Folha de S.Paulo, 21/01/03.

11.Casos mencionados com freqüência: a construção de Brasília, da Rodovia Transamazônica e da Ponte Rio-Niterói.

12. Para Antoninho Marmo Trevisan, auditor, há três pontos vulneráveis à fraude: o sistema eletrônico, o processo de concessão de benefícios e a sonegação pelas empresas.

\section{Especialmente de grandes empresas e bancos.}

14. Conforme admitido pelo ministro-chefe da Casa Civil José Dirceu em seminário do PT (MARQUES, 2003).

15. Fator previdenciário, estabelecido pela Lei n. 9.876, de 29/11/99, é uma fórmula que considera os seguintes elementos: tempo de contribuição; alíquota de contribuição $(0,31)$; idade e expectativa de vida do segurado, na data da aposentadoria (MPAS, 2002:23). A regra de cálculo do valor dos benefícios, pós-reforma de 1998, é a seguinte:

$\mathrm{Sb}=\mathrm{Mx}[(\mathrm{TC} \times \mathrm{a}) / \mathrm{Es}] \mathrm{x}[1+(\mathrm{Id}+\mathrm{Tc} \times \mathrm{a}) / 100]$

$\mathrm{Sb}=$ salário de benefício

$\mathrm{M}=$ média dentre os $80 \%$ dos salários de contribuição apurados entre julho de 1994 e o momento da aposentadoria, corrigidos pela inflação Tc $=$ tempo de contribuição do segurado

$\mathrm{a}=$ alíquota de contribuição do segurado e do empregador $=0,31$

Es = expectativa de sobrevida do segurado na data da aposentadoria, medida anualmente pelo IBGE, considerando-se a média única nacional para ambos os sexos

Id = idade do segurado na data da aposentadoria

16. Ver, a propósito, texto de Luís Nassif publicado na Folha de S.Paulo $(13 / 10 / 00)$, que aponta as conseqüências da utilização da "tábua da vida", argumentando que "o poço continuará sem fundo enquanto não se fizer um corte radical, implantando o novo sistema para quem entrar agora e aportando ativos para garantir o atual passivo previdenciário" e que a "grande revolução que está ocorrendo na Previdência é gerencial".

17. São constatações de um ardoroso defensor da reforma - Chico Previdência, o autor aqui citado, para o qual "trata-se de alterar a própria lógica de funcionamento, substituindo-se, pelo menos parcialmente, o inexoravelmente falido regime de repartição pelo de capitalização" (OLIVEIRA, 2000, p. 2, grifos meus).

18. Ministro Ricardo Berzoini em entrevista ao Correio Brasiliense, $10 / 01 / 03$.

19. Conforme entrevista do ministro Ricardo Berzoini ao Correio Brasiliense, 10/01/03.

20. O equilíbrio seria alcançado pela equivalência do valor presente das contribuições ao valor presente dos benefícios (MPAS, 1999, p. 4, NR 6).
21. Direito à aposentadoria integral para o tempo já trabalhado, sendo que o tempo restante seria igual à soma do tempo de serviço anterior à reforma dividido por 35 anos e do tempo de serviço posterior à reforma dividido por 35 anos.

22. Conforme a reportagem "Como ficou o relatório da reforma da Previdência", Folha de S.Paulo, 18/07/03 (grifos meus): “Já o texto votado em segundo turno apresentou as seguintes alterações: um redutor de ganhos para quem antecipar a aposentadoria, de 5\% para cada ano até o máximo de $35 \%$; aumento do subteto do Judiciário Estadual para 90,25\% do salário do ministro do STF; além das demais, exigência de permanência de cinco anos no último cargo, para aposentadoria integral; aumento de 70 para 75 anos da idade para aposentadoria compulsória a partir de 2012 ; teto de $\mathrm{R} \$ 2.400,00$ para futuros pensionistas e desconto de $30 \%$ sobre a parcela excedente; contribuição de $11 \%$ sobre a parcela da aposentadoria ou pensão (inativos) que exceder a R\$ 1.200,00, no caso dos Estados e Municípios, e R\$ $1.400,00$, no caso da União. Para atuais servidores o teto de isenção, quando se aposentarem, será de R\$2.400,00. O teto do INSS sobe de R\$ $1.869,34$ para R\$2.400,00. Os fundos de pensão a serem criados após a reforma serão fechados, públicos e com contribuição definida, ou seja, o beneficiário saberá quanto pagar, mas não quanto receber de aposentadoria. Militares e policiais militares de todos os Estados terão, segundo o governo, projeto específico de reforma". Conferir "Como ficou a proposta", Folha de S.Paulo, 15/ 08/03. Em 19/12/03, foi promulgada a Emenda Constitucional n. 41 pelo Congresso Nacional. Entre outros aspectos, acima descritos, o texto estabelece a contribuição dos inativos e aumenta a idade mínima para a aposentadoria (60 anos para o homem e 55 para a mulher). Mas o Senado fez modificações no texto original da reforma e aprovou em segundo turno a PEC paralela, a ser apreciada pela Câmara dos Deputados, contendo aspectos favoráveis aos atuais servidores públicos, trabalhadores informais, pessoas com deficiência física e aposentados e pensionistas com doenças incapacitantes. Até o encerramento deste artigo a Câmara ainda não tinha votado a PEC paralela.

23. Em favor da preservação da integralidade dos vencimentos, os militares arrolam as condições sob as quais exercem a sua função: dedicação exclusiva, disponibilidade permanente, transferências constantes, horas extras não remuneradas, não pagamento de adicional noturno, ausência de FGTS, proibição de exercício de atividade profissional paralela, possibilidade de convocação na reserva, baixos salários na ativa, contribuição de 7,5\% pelos inativos. Os juizes, por sua vez, apontam a carreira específica com limitações funcionais, o acúmulo de cargo somente pela docência, a proibição de filiação a partidos políticos, o impedimento de participar de sociedades comerciais. Já os funcionários da Justiça Federal destacam o contrato de adesão no ingresso, as regras predefinidas, o exercício de funções com implicações sobre o jurisdicionado, a contribuição previdenciária sobre o total dos vencimentos e não sobre um teto, como no caso do INSS, e, como exemplo, a situação dos oficiais de justiça que se sujeitam a riscos para fazer cumprir as decisões judiciais (cf. Folha de S.Paulo, 14/01/03, p. A-4; O Estado de S.Paulo, 17/01/03, p. A-7; teses aprovadas na plenária da Federação Nacional de Servidores do Judiciário Federal - Fenajufe, Agência Fenajufe de Notícias, Brasília, 04/12/02).

24. Trata-se de artigo assinado por Marco Aurélio de Freitas Lisboa, publicado no sítio da organização: <http://www.unafisco.org.br>.

25. Segundo o Presidente da Unafisco Sindical, Paulo Gil Introíni, em entrevista à Folha de S.Paulo, 21/01/03. O sindicato representa 16 mil pessoas entre ativos, aposentados e pensionistas.

26. Por oposição ao desemprego voluntário, friccional, temporário, ocasional ou sazonal.

27. Ver, a propósito, a reportagem "Lobby quer gerir pensão do funcionalismo", Folha de S.Paulo, 26/05/03, segundo a qual bancos e seguradoras criticam teto de $\mathrm{R} \$ 2.400,00$ e tentam influir na reforma do sistema complementar público. 
28. Ocorre que, segundo a mesma fonte, vem caindo o percentual de inscritos efetivamente contribuintes, de $55,3 \%$, em 1995 , para $30,3 \%$, em 2001, o que inviabiliza o regime de capitalização individual.

29. É interessante a apresentação de duas concepções de seguro: a anglo-saxã (seguro marítimo - navegação de longo curso -, de mercado) e a alpina (seguro institucional, solidário, mutualista).

30. O governo desistiu do regime único, que não consta do relatório da comissão parlamentar concluído em meados de julho de 2003.

31. Na América Latina, especialmente no Peru, na Guatemala e na Bolívia, 20\% dos lares - uma em cada cinco famílias - são chefiados por mulheres. No Brasil, inúmeros estudos vêm apontando o crescente papel feminino na gestão da família, a par da "feminização" da pobreza. Entre os idosos, a maioria é do sexo feminino, conforme o IBGE.

32. Tanto no plano nacional como no internacional. Para o âmbito internacional, considera-se atual, oportuna e pertinente a proposta do professor americano James Tobin, de 1972, de criação de um tributo sobre as operações de câmbio. "Tributar as operações de câmbio para penalizar a especulação, controlar o movimento de capitais de curto prazo significa fazer uma séria advertência política aos principais agentes econômicos e afirmar que o interesse geral deve prevalecer sobre os interesses particulares e a necessidade de desenvolvimento sobre a especulação internacional [...] O economista americano Howard Watchell sustenta que seria preciso pelo menos três taxas para controlar o capital: além do tributo sobre as operações cambiais, um sobre os investimentos diretos no exterior e, por fim, um tributo internacional uniforme (ou 'tributo único') sobre os lucros. Ademais, é óbvio que o parasitismo financeiro não poderá ser estrangulado sem que se ataquem os mecanismos que o sustentam. O que está em jogo é o caráter sistêmico do processo de mundialização dos mercados financeiros, bem como os fundamentos rentistas dos mecanismos de apropriação e de transferência internacional do valor e da riqueza" (CHESNAIS, 1999, p. 12;15).

33. Em julho de 2003, o salário mínimo era de $\mathrm{R} \$ 240,00$.

34. Conforme Balbi (2003, p. A-6): "só 1,5\% dos servidores civis do Executivo receberam mais de R $\$ 8.500,00$ mensais nos 12 meses encerrados em setembro passado", citando Sonoe Sugahara, do Ipea. Mil servidores ganham acima de R\$ 20 mil por mês, segundo Amaral e Barelli (2003, p. 36).

35. Caldas (2003, p. A-4), citando estimativa feita pelo Partido dos Trabalhadores.

36. A propósito, foi de $74,6 \%$ o aumento da captação dos planos de previdência privada no primeiro trimestre de 2003 , em comparação a igual período de 2002 (Folha de S.Paulo, 26/5/03). A proposta de reforma, antes mesmo de sua votação no Congresso Nacional, provocou uma corrida à previdência privada, que tem crescimento médio anual no setor entre $35 \%$ e $40 \%$ (conforme a Associação Nacional de Previdência Privada - ANAPP no Diário do Nordeste, 19/04/03).

37. Ver, a propósito, Chesnais (1999, p. 31-ss), sobre o poderio das instituições financeiras e sua perversa participação nos ataques especulativos que provocaram as crises cambiais de 1992 e 1993 . Deles participaram: os 30 maiores bancos, os fundos especulativos especializados - hedge funds -, dentre os quais a sociedade Quantum Funds, de George Soros, os fundos de pensão (investidores institucionais) e os fundos mútuos de investimento "que decidem o resultado do conflito travado no mercado cambial, em detrimento dos governos e a favor do melhor meio de lhes impor suas exigências [...] o efeito desestabilizador sobre os mercados (de câmbio e de títulos) desencadeado por esses investidores institucionais é incomensurável".

\section{REFERÊNCIAS BIBLIOGRÁFICAS}

ALBERTI, V. (Coord.); et al. Entre a solidariedade e o risco: história do seguro privado no Brasil. Rio de Janeiro: Fundação Escola Nacional de Seguros e Fundação Getúlio Vargas, 1998.
AMARAL, L.H.; BARELLI, S. Começou mal a reforma da previdência. Veja, São Paulo, n. 3, ed. 1.786, 22 jan. 2003.

ASSOCIAÇÃO NACIONAL DOS FISCAIS DE CONTRIBUIÇÕES PREVIDENCIÁRIAS - ANFIP. Seguridade e desenvolvimento: um projeto para o Brasil. Brasília, DF: 2002.

BALBI, S. Aposentados levam $42 \%$ da folha da União. O Estado de S.Paulo, São Paulo, p. A-6, 13 jan. 2003.

CALDAS, S. Estados são maior obstáculo à reforma de Berzoini. $O$ Estado de S.Paulo, São Paulo, p.A-4, 12 jan. 2003a.

PT foi contra projeto igual, afirma ex-secretário. O Estado de S.Paulo, São Paulo, p. A-6, 12 jan. 2003b.

CECHIN, J. A previdência social reavaliada II. Revista Conjuntura Social, Brasília, DF, MPAS, 2002.

CHESNAIS, F. Tobin or not Tobin. Porque tributar o capital financeiro internacional em apoio aos cidadãos. São Paulo, Unesp, ATTAC, 1999.

CUT. CUT defenderá fim da aposentadoria diferenciada de militares e juízes. São Paulo, 16 jan. 2003. (Seção Brasil - AE). Disponível em: <http://www.cut.org.br>.

Previdência social. Presente e futuro da previdência pública, complementar e dos servidores públicos. In: $10^{\text {a }}$ Plenária Nacional. São Paulo, 08 a 11 maio 2002. Disponível em: $<$ http://www.cut.org.br $>$.

Quem perde com a reforma. Projeto de FHC impõe limite de idade e novo cálculo reduz a aposentadoria em 50\%. São Paulo, s.d. Disponível em: < http://www.cut.org.br $>$.

DELGADO, G.; SCHWARZER, H. Evolução histórico-legal e as formas de financiamento da Previdência Rural no Brasil. s.d.

EXAME. Reforma da previdência: quem vai pagar a aposentadoria dele? São Paulo, ed. 783, 15 jan. 2003.

FALEIROS, V. de P. A questão da reforma da previdência social no Brasil. Revista Ser Social, Brasília, DF, UNB, n. 7, 2000.

FENAJUFE. Deu na imprensa. Brasília, DF: 2003. Disponível em: $<$ http://www.fenajufe.org.br>. Acesso em: 10 jan. 2003.

Teses aprovadas na plenária da Fenajufe. Brasília, DF: 2002. Disponível em: <http://www.fenajufe.org.br $>$. Acesso em: 4 dez. 2002.

GUSHIKEN, L. et al. Regime próprio de previdência dos servidores: como implementar? Uma visão prática e teórica. Brasília, DF: MPAS, 2002. (Série Estudos).

IPEA. Politicas sociais. Acompanhamento e análise. Brasília, DF, n. 5, ago. 2002.

LAHÓZ, A. É para ontem. Porque a reforma da previdência é a principal tarefa do governo Lula. Exame, São Paulo, n. 1, ed. 783, p. 35-ss, 15 jan. 2003.

LISBOA, M.A. de F. A reforma da previdência e a nossa aposentadoria. Brasília, DF: s.d. Disponível em: $<$ http://www.unafisco.org.br>.

MARQUES, R.M. E se a previdência não tiver déficit? In: SEMINÁRIO: A REFORMA DA PREVIDÊNCIA. São Paulo, PT e Fundação Perseu Abramo, maio 2003. Disponível em: $<$ http://www.cirandabrasil $>$.

MARQUES, R.M.; BATICH, M.; MENDES, Á. Previdência social brasileira: um balanço da reforma. São Paulo em Perspectiva, São Paulo, Fundação Seade, v. 17, n. 1, p. 111-121, jan./mar. 2003. Disponível em: <http://www.seade.gov.br>.

MIRANDA, R.B. Três modelos teóricos para a previdência social. Brasília, DF, Ipea, 1997. (Texto para discussão, n. 516). 
MORAES, M.V.E. O futuro da seguridade social. Reforma previdenciária, Vetores do debate contemporâneo, São Paulo: Centro de Estudos da Fundação Konrad Adenauer, 1999. (Série Debates, n. 19).

MPAS. Tudo o que você quer saber sobre a previdência social. 2. ed. Brasília, DF: 2002.

A nova regra de cálculo dos benefícios: o fator beneficiário. Informe da Previdencia Social, Brasília, DF, v. 11, n. 11, nov. 1999.

NASSIF, L. A síntese da reforma da previdência. Folha de S.Paulo, São Paulo, 13 jan. 2000.

OLIVEIRA, F. Quando chegará o dia da reforma da previdência? Economia em perspectiva. Carta de Conjuntura, São Paulo, Corecon-SP, n. 175, 2000.

OLIVEIRA, F.E.B. de.; BELTRÃO, K.I.; PASINATO, M.T.M. Entidades de previdência privada: financiamento do desenvolvimento no Brasil. Reforma previdenciária - Vetores do debate contemporâneo, São Paulo, Centro de Estudos da Fundação Konrad Adenauer, 1999. (Série Debates, n.19).

OTTA, L.A.; MURPHY, P. Mercado aposta tudo na reforma da previdência. O Estado de S.Paulo, São Paulo, 19 maio 2003.

PENNA, A.F. O fator previdenciário: o destino de todos. Campinas: Adunicamp, dez. 1999. Caderno Especial. Disponível em: $<$ http://www.adunicamp.org.br>. Acesso em: jun. 2003.
PEREIRA, P.A.P. Por uma nova concepção de seguridade social. Revista Ser Social, Brasília, DF, UNB, n. 7, 2000.

PINHEIRO, V.C. A experiencia brasileira. Reformas dos sistemas de pensão na América Latina. Brasília, DF: MPAS, 2001.

SCHWARZER, H. Algumas anotações sobre equívocos conceituais na discussão das reformas previdenciárias na América Latina. Reforma previdenciária - Vetores do debate contemporâneo, São Paulo, Centro de Estudos da Fundação Konrad Adenauer, 1999. (Série Debates, n. 19).

O "modelo chileno" vale o que custa? Folha de S.Paulo, São Paulo, 28 set. 1997.

SILVA, A.A. da. A gestão da seguridade social brasileira: entre a política pública e a competitividade mercantil. Tese (Doutorado) - PUC-SP, São Paulo, 2003.

TAVARES, L. Não há déficit no sistema de previdência. Folha de S.Paulo, São Paulo, 22 jun. 2003.

VEJA. Reforma da previdência: ninguém quer largar o osso. São Paulo, ed. $1.786,22$ jan. 2003.

Ademir Alves da Silva: Professor de Politica Social e Serviço Social nos cursos de Serviço Social e de Relações Internacionais da PUC-SP, Assistente Social na Secretaria Municipal de Assistência Social de São Paulo. 